\title{
Major groundwater reservoir nr 112 in the coast of Gdańsk Bay
}

\author{
Zbigniew Kordalski ${ }^{1}$, Andrzej Sadurski ${ }^{2}$ \\ Marine Branch of Polish Geological Institute NRI, 5 Kościerska str., 80-328 Gdańsk, Poland
}

\begin{abstract}
The main groundwater reservoirs (MGR) in Poland have been established during last 9 years and finished in 2017 yr. (Mikołajków, Sadurski edit.). The most reach in groundwater resources hydrogeological structures in the country where deliminated and the scope of limited and forbidden human activities for their protection where established. Area of main groundwater reservoir nr 112 , named - Żuławy Gdańskie - comprises predominantly City of Gdańsk and area of Gdańsk and Pruszcz Gdański Counts and slightly exceeds $100 \mathrm{~km}^{2}$. The area undertaken for the investigation and modelling was $363.8 \mathrm{~km}^{2}$. The aim of MGR delimitation and hydrogeological documentation was the water resources protection based on physical planning proper, responsible water management (Herbich et al., 2009). The methods of hydrogeological researches, groundwater resources calculation and delimitation of MGR is presented in the paper.
\end{abstract}

\section{LOCATION AND NATURAL CONDITIONS}

133 major groundwater reservoirs, named later MGR, were established in the country during last 9 years (www.psh.gov.pl). Some of them are in the coastal zone of the Southern Baltic Sea, as shown on fig. 1. MGR nr 112 is in the area of Gdańsk region and is presented in the paper. Investigation area is situated on the boundary area of moraine plateau of Cashubian Lakeland, western part of Vistula delta plain and Gdańsk Bay, and is given on fig. 1. The MGR nr 112 comprises two parts, one on the Vistula delta in the South and second one on the seaside terrace in Gdansk in the North. The Mesozoic strata that belong to the young cover of East European Platform are finished in Upper Cretaceous by the marine sediments.

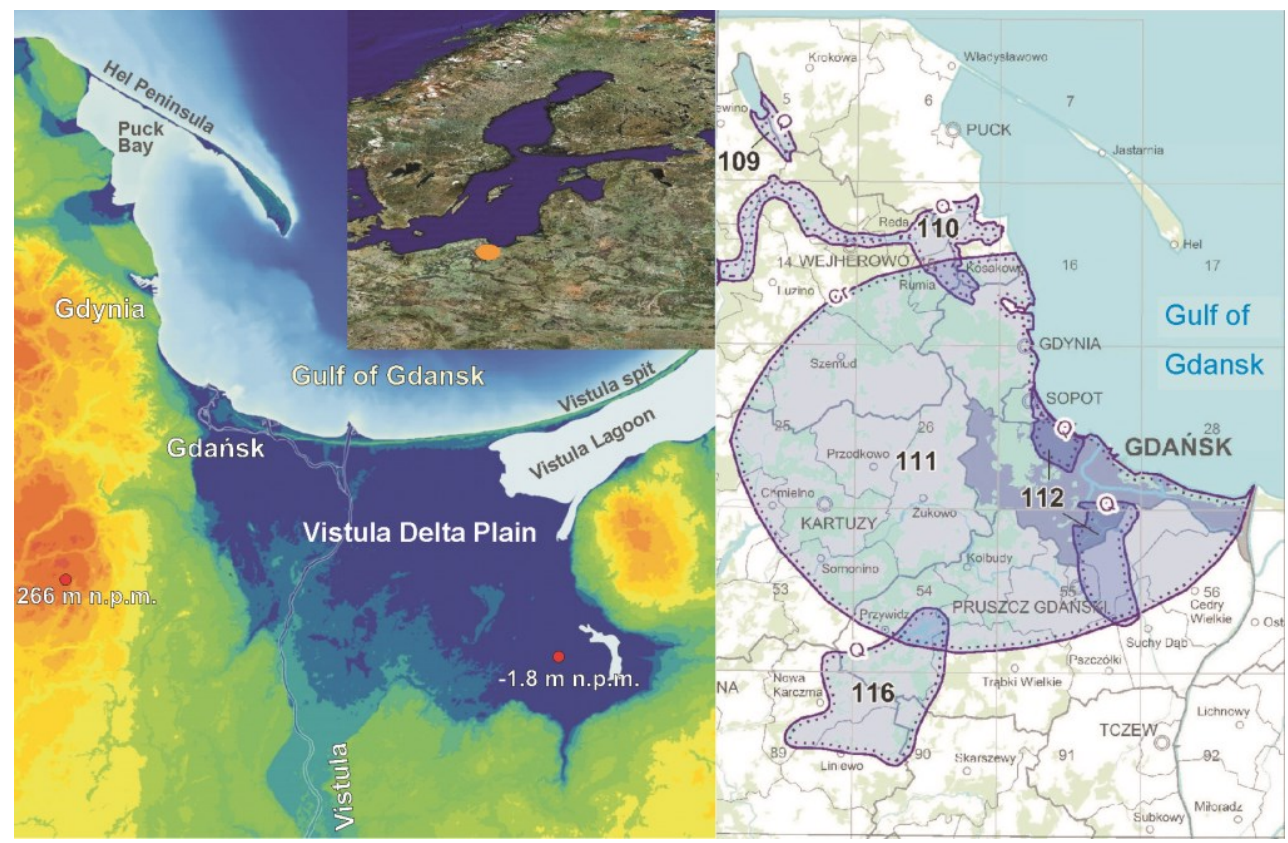

Figure 1. Location of the MGR 112 in the coastal area of Gdańsk Bay after Mikołajków et al. (2017). 
Lithology of Cretaceous strata cause the limitation of regional circulation system and depth of fresh groundwater occurrence (Sadurski, 1989). In the middle of Cretaceous sediments extends sandy series with glauconite. Thickness of this series is up to $200 \mathrm{~m}$ in the central part of the MGR nr 111, named Gdańsk Upper Cretaceous reservoir. Above this series, in the roof of Cretaceous occur marls, sandy limestones and gaizes. The roof of Cretaceous on the area of MGR nr 112 was stated on the ordinates from 90 to $100 \mathrm{~m}$ b.s.l. The Cainozoic and Cretaceous aquifers create the multilayer water bearing system in the regional, transition and local groundwater circulations recognized (Kozerski edit. 2007).

The regional base of drainage of MGR nr 111 and 112 is the Gdańsk Bay, Vistula delta plane and Seaside terrace in Gdańsk. This is also the limit of two hydrogeochemical environments; salty and brackish sea water and fresh inland groundwater.

The groundwater of Quaternary aquifer are fresh of $\mathrm{HCO}_{3}-\mathrm{Ca}$ chemical type, locally needs only simple treatment in the water works station due to iron and manganese natural enrichment.

\section{GROUNDWATER RESOURCES}

Groundwater resources of MGR nr 112, that could be used for water supply, have been calculated separately for distinguished aquifers being hydraulic connection as the regional system. The total value of groundwater resources of quaternary aquifer is $2900 \mathrm{~m}^{3} / \mathrm{h}$, but $2700 \mathrm{~m}^{3} / \mathrm{h}$ (it means 23,652 million $\mathrm{m}^{3} / \mathrm{a}$ ) came from the area of MGR $\mathrm{nr} 112$.

The biggest groundwater extraction in the area of Gdańsk and Sopot cities has been registered during the second part of $80 \mathrm{yr}$ of XX century and the total exploitation of water intakes reached $8000 \mathrm{~m}^{3} / \mathrm{h}$. This total value of exploitation exceeded natural, renewable resources and caused bad chemical state - salt water intrusion and dynamic - hydraulic head and flows in many places of the area. Since 90. of XX century is observed decline of groundwater exploitation up to $3000 \mathrm{~m}^{3} / \mathrm{h}$ at present (Szelewicka, Kordalski 2013). Groundwater intakes are only source for water supply in the area of MGR nr 112 and also MGR nr 111. The groundwater are dominant for municipal and industrial water works.

\section{CONCEPTUAL MODEL}

Hydrogeological, conceptual model comprises layout of the strata extends, aquifers geometry and properties and also semi permeable strata and map of hydraulic heads of the groundwater of different aquifers, that is the initial boundary condition. Scheme of hydrogeological profiles 2 according to description given in table 2.is presented on the on figure below.

Delimitation of the MGR nr 112 limits and its protection area was done using the criteria elaborated for the whole country (Herbich et al., 2009):

- $\quad$ safe yield of the Wells $\mathrm{Q}>70 \mathrm{~m}^{3} / \mathrm{h}$,

- transmissivity of the aquifer $\mathrm{T}>10 \mathrm{~m}^{2} / \mathrm{h}$,

- good quality state of groundwater,

- $\quad$ possibility of new construction of water intake of high exploitation ratio $Q>10000 \mathrm{~m}^{3} / 24$ h. 
Table. 1. Profile of modelled strata (I, III, V - semipermeable, separation strata; II, IV, VI - aquifers).

\begin{tabular}{|c|l|}
\hline $\begin{array}{c}\text { Numer and profile } \\
\text { of modelled strata }\end{array}$ & \multicolumn{1}{c|}{ Characteristics of modelled strata } \\
\hline $\begin{array}{c}\text { I } \\
\text { Convertible }\end{array}$ & Impermeable sediments near terrain surface, locally with sands. \\
\hline $\begin{array}{c}\text { II } \\
\text { Convertible }\end{array}$ & Quaternary - Miocene porous aquifer, mainly sands, loams and gravel. \\
\hline $\begin{array}{c}\text { III } \\
\text { Confined }\end{array}$ & $\begin{array}{l}\text { Miocene and lower Pleistocene aquifer - fine sands, sands and also silts and } \\
\text { glacial tills. }\end{array}$ \\
\hline $\begin{array}{c}\text { IV } \\
\text { Confined }\end{array}$ & $\begin{array}{l}\text { Oligocene sands of Oligocene and sand and gravel in buried structure of } \\
\text { Pleistocene, mainly on the Seaside Terrace and in the Vistula delta plane. }\end{array}$ \\
\hline $\begin{array}{c}\text { V } \\
\text { Confined }\end{array}$ & $\begin{array}{l}\text { Impermeable and semi permeable sediments - silts and loams of Paleogene } \\
\text { and roof of Cretaceous - gaizes, marls and sandy limestones. }\end{array}$ \\
\hline $\begin{array}{c}\text { VI } \\
\text { Confined }\end{array}$ & Main aquifer of Cretaceous - sands with glauconite (MGR 111). \\
\hline \multicolumn{2}{|c|}{} \\
\hline
\end{tabular}
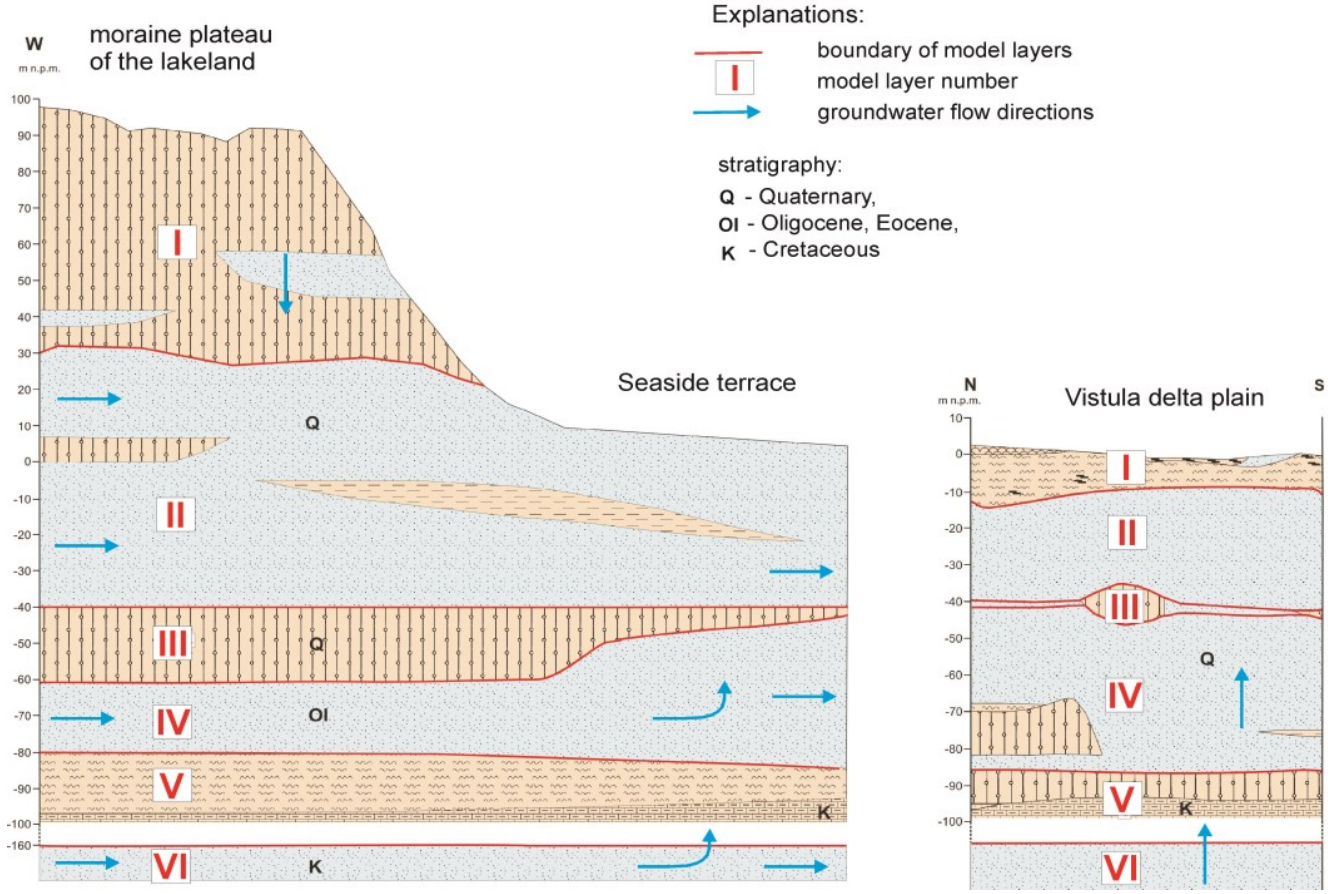

Figure 2. Hydrogeological diagram of the conceptual model of groundwater flows.

\section{MOTHODS OF INVESTIGATION}

Realization of these objectives needed many investigations and solutions, as follow:

a) hydrogeological (conceptual) model of MGR construction, that include the 3D distribution of hydraulic and geological parameters to establish the boundary condition of the aquifers,

b) verification of groundwater reservoir parameters for water resources and intensity of groundwater flow, 
c) optimum location of new water intakes and their protection area estimation.

Chemical analysis of groundwater samples comprises mainly: TDS, Temperature, electrolytic conductivity, colour, $\mathrm{pH}$, basicity, $\mathrm{NH}_{4}, \mathrm{NO}_{3}, \mathrm{NO}_{2}, \mathrm{Cl}, \mathrm{SO}_{3}, \mathrm{Na}, \mathrm{K}, \mathrm{Ca}, \mathrm{Mg}$, phosphates, fluorine, iron compounds, manganese, bicarbonates, silica and also $\mathrm{Br}, \mathrm{B}, \mathrm{Ba}, \mathrm{P}$, Ti, Li, Be, V, Co, Ni, As, Se, Mo, Ag, Cd, Sn, Sb, Tl, U, BTX, pesticides, PAH and mercury.

\section{NUMERICAL MODEL}

Investigation area was divided into grid $\Delta x=\Delta y=200 \mathrm{~m}$, in 124 columns and 153 rows. The total area cover $363.8 \mathrm{~km}^{2}$. Distribution of calculation grid was sufficient for analysis of groundwater flow area and for imaging of geological structures reflection together with hydrogeological and hydraulic properties in frames of the MGR 112.

The code MODFLOW-2000 (MODular FLOW, 1996) as a part of Groundwater Modeling System (GMS) was used for the simulation of groundwater flow in the water reservoir considered. For the water balance estimation the code ZONE BUDGET was used.

Identification and test of model has been carried by the difference value between measured hydraulic head and calculated on the model. The next goal of model investigation was the protection area of proposed two parts of MGR $\mathrm{nr} 112$. It results from the 25 th years flow time of groundwater, including the time of vertical percolation from the surface.

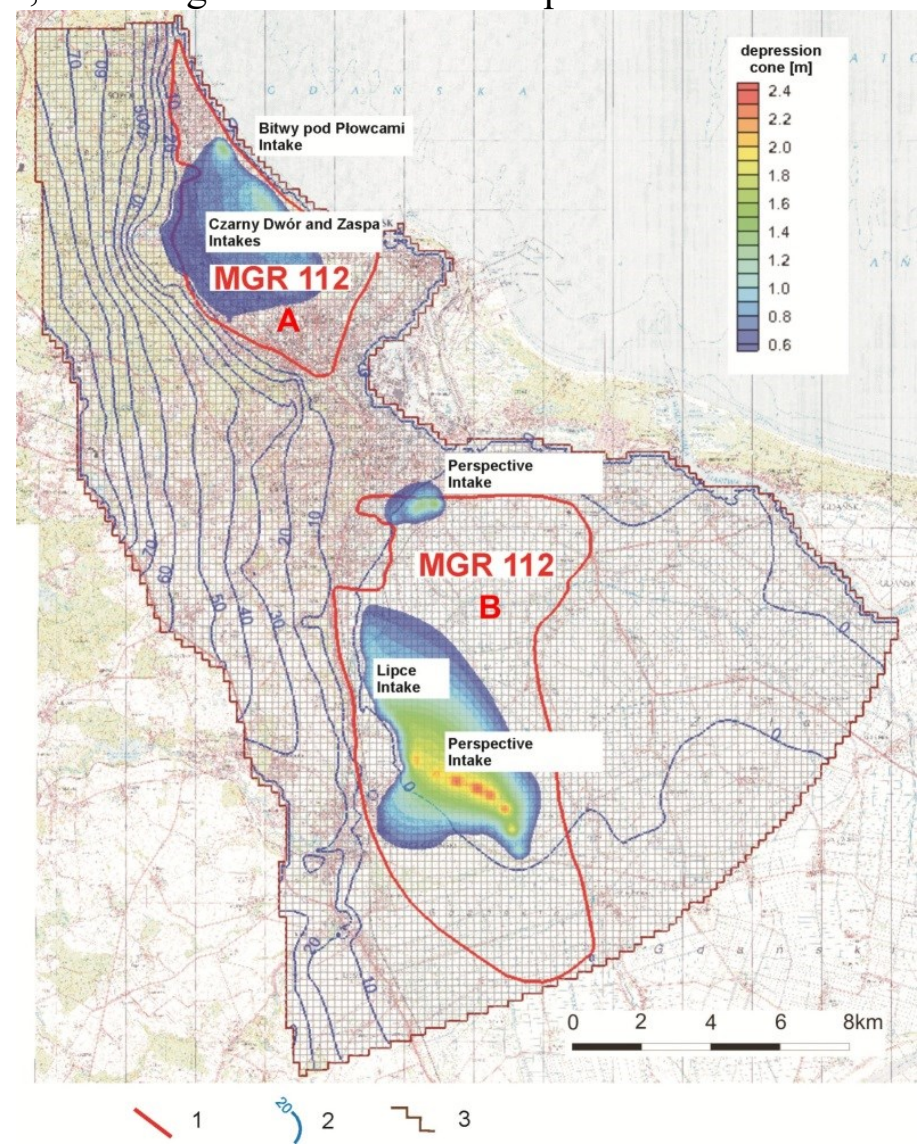

Figure 3. Contour lines of hydraulic head distribution and depression cone of water intakes at safe yield value of groundwater. Explanation: 1 - limit of the reservoir; 2 hydraulic head of Quaternary aquifer of MGR nr 112; 3 - boundary of the investigation area. 


\section{CONCLUSIONS}

There are two MGR in the area of Gdańsk region; one nr 112 was established as HolocenePleistocene aquifers and the second one is nr 111 recognized in the Cretaceous strata, below. Potential reason of the groundwater resorces pollution are serious for the first MGR $\mathrm{nr} 112$ and can be mentioned as overexploitationm of water intakes, dumping site and sewage and industrial pollutants also from the past centuries. Percolation and flow time of groundwater is a good criterion for estimation of vulnerability of the area on the surface of MGR $\mathrm{nr} 112$. The protection area of MGR was determine for isochrone of 5, 15 and 25 years of percolation and flow time of water. Very high and high vulnerability of the quaternary aquifer range $66.9 \mathrm{~km}^{2}$ in part A in the North and $52.4 \mathrm{~km}^{2}$ in part B in the South (see fig. 3). Total protection area comprises $119.3 \mathrm{~km}^{2}$.

Forecast of the pollutants migration time to the wells was possible by groundwater flow modelling for each of MGR also in the coastal area of the Baltic Sea. Calculation of safe yield was done by modelling too, especially according to the risk of salt water intrusion. The safe, total exploitation of the wells of water intakes of this reservoir has been calculated and referes to the both parts of the MGR under consideration. Restrictions and limitation on surface within the protection area implemented to the developing plans of the Gdańsk City.

\section{REFERENCES}

McDonald M. G., Harbaugh A. W., 1996 - User's Documentation for MODFLOW-96, an update to the U.S. Geological Survey Modular Finite-Difference Ground-Water Flow Model, U.S. Geological Survey.

Herbich P., Kapuściński J., Nowicki K., Prażak J., Skrzypczyk L., 2009 - Merthod of the protection area of MGR delimitation for developing planes and water management plan sof the river basins. Ministra of Environment Publ. Warsaw.

Kozerski B., edit., 2007 - Gdańsk’s Hydrogeological Flow System. Techn. Univ. of Gdańsk Publ. Gdańsk.

Mikołajków J., Sadurski A. edit., 2017 - Major Groundwate Reservoirs in Poland, [in polish]. PGINRI Publ. Warsaw.

Mikołajków J. et al., 2017 - Map of Major Groundwater Reservoirs in Poland, [in polish]. PGI-NRI Publ. Warsaw.

Sadurski A., 1989 - Upper Cretaceous Groundwater Flow system of Eastern Pomerania. MMinning and Metal. Academy Pobl. Serie Geology, vol. 46. Cracow.

Szelewicka A., Kordalski Z., 2013 - Hydrodynamics changes in the drainage area of Hydrogeological System on the basis of recent research. Bull. of PGI-NRI, vol. 456: 595-600. Warsaw.

Szelewicka A., Karwik A., Kordalski Z., 2013 - Hydrogeological documentation of MGR nr 112 Żuławy Gdańskie for protection area establishment of this major groundwater reservoir.

Unpublished. Arch. of Marine Branch of PGI-NRI. Gdańsk. 